\section{JURNAL NERS DAN KEBIDANAN INDONESIA INDONESIAN JOURNAL OF NURSING AND MIDWIFERY}

\title{
The dynamics of jama (jamu madura-madurese traditional herbal medicine) in the viewpoint of public woman: a phenomenology study
}

\author{
Sri Yunita Suraida Salat ${ }^{1 *}$, Ahmaniyah $^{1}$, Emdat Suprayitno $^{1}$
}
${ }^{1}$ Department of Midwery, Faculty of Health Sciences, Universitas Wiraraja Jalan Raya Sumenep Pamekasan Km.5, Patean-Sumenep
${ }^{1}$ Department of Midwery, Faculty of Health Sciences, Universitas Wiraraja Jalan Raya Sumenep Pamekasan Km.5, Patean-Sumenep
${ }^{1}$ Department of Nursing, Faculty of Health Sciences, Universitas Wiraraja Jalan Raya Sumenep Pamekasan Km.5, Patean-Sumenep
${ }^{*}$ Corresponding author : yunitafik@wiraraja.ac.id

\begin{abstract}
ABSTRAK
Latar Belakang: Dengan kemajuan dan perkembangan obat yang saat ini terjadi, masih banyak masyarakat di Sumenep yang memilih jamu tradisional Madura dalam upaya pencegahan dan pengobatan penyakit, dalam proses kehamilan, persalinan dan masa nifas. Kebiasaan ini diberikan secara turun menurun oleh para leluhur di daerah Sumenep. Jamu Madura dipilih karena secara umum dikenal memberikan banyak manfaat serta aman bagi kesehatan tanpa memberikan efek samping. Di Kabupaten Sumenep Madura, kebiasaan minum Jamu madura pada masa post partum (nifas) sampai saat ini masih dilakukan.
\end{abstract}

Tujuan: Penelitian ini bertujuan untuk mendeskripsikan tentang pandangan dan pendapat ibu nifas terhadap jamu nifas yang mereka konsumsi selama masa nifas yang dijalaninya.

Metode: Penelitian ini merupakan jenis penelitian diskriptif dengan mengeksplorasi budaya lokal, pengetahuan ibu nifas tentang jamu nifas dan persepsi ibu nifas tentang manfaat dari jamu mdura yang dikonsumsinya. Desain penelitian ini adalah penelitian kualitatif dengan pendekatan fenomenologi dengan jumlah partisipan 20 ibu nifas beserta keluarganya dan 2 orang pembuat jamu nifas. Pengumpulan datanya dilakukan dengan observasi langsung melalui wawancara mendalam kepada para responden.

Hasil: Hasil penelitian menunjukkan 5 tema yang menggambarkan dinamika jamu tradisional madura dalam pandangan ibu nifas, yaitu alasan konsumsi jamu tradisional nifas, bentuk jamu yang dikonsumsi, pengetahuan jamu nifas, manfaat jamu tradisional nifas, dan keinginan ibu untuk mengkonsumsi jamu nifas dikemudian hari.

Kesimpulan: Berdasarkan hasil penelitian dapat disimpulkan bahwa 20 ibu nifas yang mengkonsumsi jamu nifas memiliki sudut pandang yang beranekaragam dalam melihat jamu nifas, namun secara garis besar ibu merasakan manfaat secara langsung dari jamu nifas yang dikonsumsinya selama ini baik dalam proses pemulihan masa nifas serta dalam meningkatkan produksi ASI.

KATA KUNCI : jamu; ibu nifas; madura; dinamika; obat tradisional

\section{ABSTRACT}

Background: With the progress and development of medicine that is currently happening, there are still many people in Sumenep who choose Madurese traditional herbal medicine in an effort to prevent and to cure disease, in the process of pregnancy, childbirth and the postpartum period. This habit was inherited from their ancestors. Jamu is supposed to provide benefits and safe with no side effects. People in Sumenep still consuming herbal medicine during postpartum period as habit. 
Objectives: This study aimed to describe views and opinions of postpartum mothers on the puerperal herbal medicine that they consumed during the postpartum period.

Methods: This study exploring the local culture, postpartum mothers' knowledge about postpartum herbal medicine and their perception about its benefits. This study design was qualitative study with a phenomenological approach with total participants were 20 postpartum mothers and their families and 2 postpartum herbal medicine makers. Data were collected by direct observation through in-depth interviews.

Results: The results showed 5 themes describing the dynamics of the Madurese traditional herbal medicine in the viewpoint of post-partum mothers, namely their reasons for consuming postpartum traditional herbal medicine, the form of the herbal traditional medicine consumed, their knowledge of postpartum herbal medicine, the benefits of postpartum traditional herbal medicine, and the mother's desire to consume the puerperal herbal medicine in the future.

Conclusions: It can be concluded that there was different viewpoint that described by postpartum women about consuming postpartum herbal medicine. In general, they found that postpartum herbal medicine had benefits directly in the recovery process of the postpartum period and increasing breast milk production.

KEYWORD: herb; childbirth; madura; dinamics; indonesian traditional herbal medicine;

Article Info:

Article submitted on October 07, 2020

Article revised on January 26, 2021

Article received on March 03, 2021

DOI: http://dx.doi.org/10.21927/jnki.2020.9(1).1-10

\section{INTRODUCTION}

Jamu is a term of Indonesian traditional herbal medicine that comes from natural ingredients such as plants, animals and minerals. Herbal medicine has become a tradition in Indonesia, especially in the Sumenep district, which is one of the districts on the island of Madura (1). The people of Sumenep Regency are accustomed to consuming Jama (madurese traditional herbal medice) in their daily life. They believe that madurese traditional herbal medice has properties that are good for the condition of the human body. This has been passed down from generation to generation by the ancestors of the people of Sumenep Regency. One type of Madura herbal medicine that is still consumed is Jamu Nifas. This habit was inherited from their ancestors. Jamu is supposed to provide benefits and safe with no side effects (2).

The puerperium is a period that occurs after childbirth (3). The high number of maternal morbidity and mortality occurs during the puerperium. Many factors affect maternal health during the puerperium and one of them is culture. There are many cultures in Indonesia that are directly related to the postpartum period. Postpartum herbal medicine is one of them. Puerperal herbal medicine is believed to speed up recovery during the puerperium (4). With the progress and development of medicine that is currently happening, the people the people in Sumenep persist in using and consuming Jamu (Indonesian traditional herbal medicine) to prevent and to cure diseases, in the process of pregnancy, childbirth and the postpartum period (5). This is evidenced by a preliminary study conducted in May 2019 by interviewing 12 postpartum mothers in 3 different sub-districts. The result found that all of the 12 postpartum mothers consumed traditional herbal medicine during their postpartum period. Eight postpartum mothers said that they consuming herbal medicine once a day during postpartum period, and other said that they consuming herbal 
medicine twice a day during the postpartum period. There are many dosage forms of traditional herbal medicine, some of which are available in capsules, herbal powder or ingredients that are made directly. Postpartum herbal medicine is believed to provide benefits, such as facilitating breastfeeding, accelerating the uterine reduction process, maintaining stamina and the health of postpartum mothers. The benefits of puerperal herbal medicine for expediting breastfeeding were also studied by Kumlasari in 2014, which showed that $100 \%$ of mothers who consumed postpartum herbal medicine released their breast milk smoothly. The herbal medicine consumed is a type of herbal medicine "gepyokan" which is used to increase milk production in nursing mothers (6). In addition, in 2018 there was also a study on "Traditional Medicine (Jamu) in Postpartum Health Care and Breastfeeding in Tegal Regency" by Pratiwi, et al. The results of the study indicated that the traditional herbal medicine consumed by postpartum mothers have a composition to improve the recovery process for postpartum mothers and the production of breast milk. The traditional herbal mediceine that are consumed are herbs to maintain endurance, increase breast milk production and keep the body lean (7).

Therefore, this study aimed to obtain the description of viewpoint and opinion of postpartum mothers about their experience in consuming postpartum traditional herbal medicine. This study exploring the local culture, postpartum mothers' knowledge about postpartum herbal medicine and their perception about its benefits.

\section{MATERIALS AND METHODS}

This study design was a qualitative with a phenomenological approach. This study intended to understand the phenomena that experienced by participants in a holistic manner. This study was conducted in the work area of the UPT Puskesmas (Unit of Public Health Center) Saronggi, which is one of an area in Sumenep Regency, Madura
Island, Indonesia. There were still many postpartum mothers who consumed postpartum herbal medicine in the study setting. Participants were determined by purposive sampling.

The inclusion criteria were postpartum mothers who consume Jama (Madurese traditional herbal medicine, residing in study setting and willing to become participants in the study. Local midwives were assisting in obtaining participants that qualifying the inclusion criteria. The total number of participant was 20 postpartum mothers. The interviews also conducted with Respondent's family to ensure the accuracy of the data.

Data were collected using direct observation by conducting in-depth interviews which then analyzed through the data reduction stage data presentation - drawing conclusions. The qualitative data also checked using triangulation techniques (8).

\section{RESULTS AND DISCUSSION}

There were 20 postpartum mothers and their family who participated in this study which were spread across the Saronggi district area (table 1). Apart from 20 postpartum mothers, the interview was also conducted with 2 postpartum herbalists who produced postpartum traditional herbal medicine. The characteristics of the seller and maker of postpartum herbal medicine are presented in Table 2.

\section{DISCUSSION}

The results showed that the dynamics of Jamu Madura in the viewpoint of the post- partum mother were divided into several discussion themes as follows:

Theme 1: Reasons for Postpartum mothers consuming the postpartum traditional herbal medicine during postpartum period

Postpartum mothers had various reasons for consuming the postpartum traditional herbal 
Table 1. Characteristics of woman who consume traditional herbal medicine during their postpartum period

\begin{tabular}{lclcl}
\hline \multicolumn{1}{c}{ Initial } & Age (year) & Level of education & $\begin{array}{c}\text { Length of } \\
\text { postpartum in day }\end{array}$ & \multicolumn{1}{c}{ Origin } \\
\hline Ny. S & 25 & Diploma-4 & 28 & Langsar \\
Ny. Ri & 21 & Senior high school & 25 & Saroka \\
Ny. Ru & 27 & Bachelor degree & 23 & Saroka \\
Ny. I & 22 & Senior high school & 15 & Nambakor \\
Ny. L & 26 & Diploma-4 & 28 & Talang \\
Ny. W & 25 & Bachelor degree & 25 & Pagarbatu \\
Ny. Sr & 25 & Bachelor degree & 19 & Kebundadap Timur \\
Ny. Dw & 20 & Senior high school & 16 & Talang \\
Ny. E & 17 & Junior high school & 21 & Talang \\
Ny. T & 20 & Junior high school & 26 & Aeng Tongtong \\
Ny. Si & 24 & Bachelor degree & 17 & Langsar \\
Ny. F & 23 & Bachelor degree & 16 & Pagarbatu \\
Ny. Ds & 29 & Bachelor degree & 27 & Langsar \\
Ny. Di & 22 & Senior high school & 24 & Kebundadap Barat \\
Ny. Ln & 27 & Bachelor degree & 18 & Saroka \\
Ny. Rs & 26 & Bachelor degree & 21 & Saroka \\
Ny. Ft & 22 & Senior high school & 17 & Talang \\
Ny. N & 27 & Bachelor degree & 28 & Tanah Merah \\
Ny. Ik & 33 & Bachelor degree & 24 & Talang \\
Ny. Ri & 24 & Senior high school & 26 & Langsar \\
\hline Data so & & & & \\
\hline
\end{tabular}

Data source: primary data 2020

Table 2. Madurese herbal traditional ingredients

\begin{tabular}{ll}
\hline \multicolumn{1}{c}{$\begin{array}{c}\text { Types/ } \\
\text { Variants }\end{array}$} & \multicolumn{1}{c}{ Herbal ingredients } \\
\hline Jamu & Temu Lawak (Curcuma zanthorrhiza), \\
Papejje & Temu Ireng (Curcuma aeruginosa), Alba, \\
& Fennel, Polasare, Cinnamon, Sentok, \\
& Jengatep, Coriander, Angina Wood, \\
& Samarantok, Prabes Leaves \\
Jamu Parem & Temu Lawak (Curcuma zanthorrhiza), \\
& Temu Ireng (Curcuma aeruginosa), Alba, \\
& Fennel, Polasare, Cinnamon, Pandieng, \\
& Sentok, Jengatep, Coriander, Angina \\
& Wood, Samarantok, Leaf of Prawn \\
Jamu & Temu Lawak (Curcuma zanthorrhiza), \\
Bangkes & Temu Ireng (Curcuma aeruginosa), Alba, \\
& Fennel, Polasare, Cinnamon, Pandieng, \\
& Sentok, Jengatep, Coriander, Angina \\
& Wood, Samarantok, Prabes Leaves, \\
& Galangal \\
& Majakani, Majakeleng, Areca, Meeting \\
& wood, White Pomegranate, Koncepet, \\
& Konce Koning, Alba, Congcong pandan, \\
& Jelawe, Jinten ireng, Fennel, Polasare, \\
& Masoji.
\end{tabular}

Data source: primary data 2020

medicine during postpartum period. $55 \%$ mothers stated that their behavior of consuming the postpartum traditional herbal medicine were based on advice that received from others. $64 \%$ postpartum mothers received advice from their parents, and $36 \%$ postpartum mothers received advice from their mother's in-laws. This information provided by participant was in accordance with the statements from their family. The culture of consuming postpartum traditional herbal medicine had existed for a long time in Sumenep Regency which continues to be passed down to the next generation. Even though postpartum mother stated that their behavior was based on other advice and coercion, they also practiced it as a form of obedience to their parents and partly accompanied by the belief that their parents will not give something bad to their children. This finding can be found in several statements of postpartum mothers who consume herbal medicine under coercion by others, among others:

"I was forced by my mother, so that the postpartum process is normal and the breast milk production is demand" (R5)

"My mother asked me to consume the herbal medicine so that the 
postpartum period is normal and the reproductive organs returns to its normal pre-pregnant state" (R6)

"This was a wish of my parents, they said that by consuming traditional herbal medicine during the postpartum period so that the reproductive organs are maintained" (R10)

This condition is reinforced by research conducted by Nurilicha in 2018 which examined "Factors Associated with the Use of Traditional Medicines for Postpartum Women at Puskesmas Karanggan, Bogor Regency", one of which is support in consuming herbal medicine. The results showed that there was an effect of support on the use of postpartum herbal medicine with a value of 0.000 , $\alpha$. (9)

Meanwhile, $45 \%$ other postpartum mothers consumed the postpartum traditional herbal medicine on their own behave. As for some of the statements of postpartum mothers who consume herbal medicine based on their own wishes, such as:

"I drink on my own because I believe by drinking the postpartum traditional herbal medicine, postpartum blood does not smell rancid and I can quickly recover" (R1)

"I did it on my own because the postpartum herbal medicine can maintain the health of the reproductive organs" (R11)

"I did it on my own wishes because the puerperal herbal medicine can accelerate the discharge of postpartum blood and breast milk" (R13)

The study finding showed that mothers who consume postpartum herbs on their own believed that the culture of consuming postpartum herbal medicine that they undergo can provide benefits in the process of returning the reproductive organs and improving the breast milk production. Culture greatly influences a person's behavior. As a research conducted by Yunita Sari in
2017 regarding "Factors associated with the habit of drinking herbal medicine in Madurese postpartum mothers", it shows that there is a cultural relationship with the habit of drinking postpartum herbal medicine with a value of $p=0.003$. (10). This condition also occurs in Sumenep district, where the initial consumption of postpartum herbal medicine is due to the culture passed down from the ancestors.

Theme 2: Forms of postpartum traditional herbal Medicine consumed during the postpartum period

The study finding showed that the traditional herbals medicine consumed by all participants were bought or ordered. The results of interviews conducted with 2 different postpartum herbal medicine sellers, they sell traditional herbals medicine in 3 types of preparations, namely liquid form that can be consumed directly, powder form which must be brewed with water first and capsule dosage form. The most interested form of jamu are liquid and powder forms.

This study found that $75 \%$ participants consuming the postpartum traditional herbal medicine in liquid form and $25 \%$ post-partum mothers were consuming in capsule form. This result showed that most of participants in the Saronggi sub-district were still used to drinking herbal medicine in liquid form. This finding was evidenced by several statements of postpartum mothers when asked why they chose this liquid form of postpartum traditional herbal medicine:

"I always been used to drink herbal medicine in liquid form" (R1)

"I drinking liquid herbal medicine, the name is herbal medicine yes in liquid form" (R3) "I bought liquid herbal medicine and drink it directly because I found it fresher if you drink herbal medicine directly" (R7)

"It's better just to drink liquid herbal medicine " (R13) 
"I prefer drinking liquid form of traditional herbal medicine, because I do not like to drink in a form of a capsule" (R15)

There are various reasons put forward by postpartum mothers in choosing the liquid herbal medicine they consume, including because liquid herbal medicine is easier to consume and tastes faster. In addition, most postpartum mothers stated that from an early age they were accustomed to consuming herbal medicine in liquid dosage form. This data results were supported by family statement which confirmed that $75 \%$ postpartum mothers been used to drinking liquid Madurese traditional herbal medicine since they were teenagers. The habit of drinking Madurese traditional herbal medicine is not only practiced by the people of Sumenep district, but also by the Madurese community in general. Consuming Madurese traditional activity was not only done during the postpartum period but also practiced during pregnancy which is known as "jamu ayu" or jamu Kandung". This habit could not be separated from the Madurese community tradition which assumed that herbal medicine is a medium in facilitating the delivery process and can keep the mother's uterus healthy after childbirth (11).

Theme 3: Knowledge of mothers about the postpartum traditional herbal medicine

This study also revealed the mother's knowledge about the postpartum traditional herbal medicine that they consumed during the postpartum period. The finding included the types/variants of postpartum herbs, postpartum herbal ingredients and the properties of the postpartum traditional herbal medicine.

a. Types/variants of postpartum traditional herbal medicine

The results showed that all of the participants stated that they consumed different types of herbal medicine during the postpartum period. After further interviews, there were $65 \%$ postpartum mothers who clearly knew each type/variant of the puerperal herbal medicine they consumed, while $35 \%$ other postpartum mothers did not know for sure each type of herbal variant they consumed. They did not know the type because their parents were ordering and preparing the herbs for them. The results were in line with the statements from 2 postpartum herbal medicine sellers who stated that postpartum traditional herbal medicine is divided into 4 types/ variants during the postpartum period, namely:

1. Papejje Jamu: The puerperal herbal for days $1-10$

2. Jamu Parem: The puerperal herbal for childbirth days 10-20

3. Jamu Bangkes: The puerperal herbal medicine for postpartum days $20-30$

4. Jamu Pakak: The puerperal herbal for $30-40$ days

Each type/variant of these herbs has different properties. The above conditions illustrate that most postpartum mothers know about the types/variants of the traditional herbal medicine they consume. A study conducted by Handayani stated that the Madurese community is accustomed to consuming herbal medicine which consists of several types of herbal medicine that must be consumed sequentially during the period after childbirth which provides the properties of facilitating the release of postpartum blood, improving breastfeeding, overcoming aches and pains, digestive problems, irregular menstruation, eliminating unpleasant body odor and preventing infection (2).

b. Ingredients of the postpartum traditional herbal medicine

The results of interviews conducted with 2 postpartum herbal medicine sellers showed that the ingredients of postpartum herbal medicine consumed by postpartum mothers were: 
1. Jamu Papejje: Temu Lawak (Curcuma zanthorrhiza), Temu Ireng (Curcuma aeruginosa), Alba, Fennel, Polasare, Cinnamon, Sentok, Jengatep, Coriander, Angina Wood, Samarantok, Prabes Leaves

2. Jamu Parem: Temu Lawak (Curcuma zanthorrhiza), Temu Ireng (Curcuma aeruginosa), Alba, Fennel, Polasare, Cinnamon, Pandieng, Sentok, Jengatep, Coriander, Angina Wood, Samarantok, Leaf of Prawn.

3. Jamu Bangkes: Temu Lawak (Curcuma zanthorrhiza), Temu Ireng (Curcuma aeruginosa), Alba, Fennel, Polasare, Cinnamon, Pandieng, Sentok, Jengatep, Coriander, Angina Wood, Samarantok, Prabes Leaves, Galangal

4. Jamu Pakak: Majakani, Majakeleng, Areca, Meeting wood, White Pomegranate, Koncepet, Konce Koning, Alba, Congcong pandan, Jelawe, Jinten ireng, Fennel, Polasare, Masoji.

The results showed that out of 20 postpartum mothers, $85 \%$ postpartum mothers were able to mention some of the postpartum traditional herbal medicine ingredients they consumed as seen from several expressions of postpartum mothers:

"The ingredients are turmeric, pomegranate, betel, tamarind, ginger, cinnamon and many other ingredients" (R13)

"The ingredients for postpartum herbs are turmeric, ginger, betel, temu ireng (Curcuma aeruginosa Roxb.), prabes leaves, betel" (R7)

"I don't really know the complete ingredients, but what is certain is betel, turmeric, ginger, pomegranate, temu ireng (Curcuma aeruginosa Roxb.)"

"What I know about puerperal herbs is from betel, turmeric, tamarind, pomegranate, prabes leaves, cinnamon, temu ireng (Curcuma aeruginosa Roxb.), addas" (R18) "Each type seems to have different ingredients, but what is clear is that there are ingredients such as turmeric, temu lawak (Curcuma zanthorrhiza), cinnamon, prabes leaves, if I'm not mistaken, but the last one is areca nut, not tight wood like that" (R19)

Although not all ingredients can be mentioned, this result illustrated that the $85 \%$ postpartum mothers knew about the postpartum traditional herbal medicine ingredients that they had consumed. Istiqomah conducted a research in 2020 on "Analysis of Postpartum Herbal Consumption Habits in Postpartum Mothers" to see the knowledge of postpartum mothers about the composition and timing of safe consumption of postpartum herbal medicine. The result is that most of the nifaas have low knowledge of the composition of postpartum herbs (12).

c. The advantage of the postpartum traditional herbal medicine

There are 4 types / variants of the postpartum traditional herbal medicine in Madura with different properties, namely:

1. Jamu Papejje is useful for promoting breastfeeding

2. Jamu Parem is useful for shrinking the uterus

3. Jamu Bangkes is useful for removing white blood cells

4. Jamu Pakak is useful for tightening the genitals organs

The results showed that the 100\% postpartum mothers were able to mention the general effect of the postpartum traditional herbal medicine they consumed, namely to facilitate breastfeeding and blood discharge during the postpartum period, but only 9 postpartum mothers knew for sure the benefits of each type/variant. This condition illustrated that all 
postpartum mothers, whether they consume the herbal medicine forcibly or on their own, know the advantage of the herbal medicine they consuming. Herbal medicine usually consists of several medicinal plants such as majakani, dinglo bengle, turmeric, red tamarind, and white pomegranate. Each type of plant contains different phytochemicals. Majakani and white pomegranate are used to treat vaginal discharge. In addition, white pomegranate is also used as an antibacterial, and antihypertensive (2).

Theme 4: Benefits felt by mothers from consuming the postpartum traditional herbal medicine

The results showed that postpartum mothers felt various benefits from the postpartum traditional herbal medicine they consumed. However, the dominant statements were improving breast milk production and smooth postpartum blood as seen in the following statements:

"Yes, I got demand of breast milk production" (R2)

"My puerperal blood flow smoothly, and doesn't smell like rancid but normal puerperal blood" (R5)

"My postpartum discharge is smoother and faster" (R7)

"The body is fresher, the blood that comes out doesn't smell fishy" (R13) "Postpartum blood flow smoothly and breast milk production is demanding, no odor either" (R18)

"Breast milk production is demanding, the body is fit faster, the postpartum blood is also flow smoothly" (R19)

The study finding illustrated that most of postpartum mothers experienced benefit from the postpartum traditional herbal medicine they consumed. The most benefit felt by postpartum mothers is the large amount of breast milk production. In 2014, Retno Kumalasari conducted a research entitled "Giving Jamu Uyup-uyup to the smoothness of breastfeeding for postpartum mothers. The results showed that of the 15 postpartum mothers who consumed Jamu $100 \%$ of their milk output was smooth with a value of $0.000<\alpha 0.05$, which indicates the influence of Jamu uyup-uyup on the smoothness of breastfeeding (6). This is also in line with research conducted by Ahmad Baequny in 2016 which conducted research on "the effectiveness of drinking herbal medicine on breast milk production in postpartum mothers", which showed that $82.6 \%$ of postpartum mothers who consumed herbal medicine experienced smooth milk production. This is because some of the ingredients of puerperal herbal medicine contain substances that can stimulate breast milk production, such as turmeric and katuk leaves (13).

One of the ingredients of the postpartum madurese traditional herbal medicine is fennel. Fennel is a plant that contains flavonoids and coumarins which are included in the phytoestrogen group which can stimulate breast milk production. In addition, fennel is also used as an anti-inflammatory and pain relieves (14). Other ingredient of postpartum traditional herbal medicine is turmeric. Turmeric contains many nutrients that are needed by mothers during the puerperium, such as protein, curcumin, potassium, carbohydrates, phosphorus, vitamin $\mathrm{C}$ and fat. While curcuma is useful in increasing the mother's appetite (6).

Galangal (Kaempferia galanga) and temu giring (Curcuma heyneana) are also the ingredients of the postpartum traditional herbal medicine. The effect of those ingredients are giving a feeling of warmth, calmness and freshness to the body of the postpartum mother. Those effects indirectly calming mother's psychological condition and stimulate the oxytocin production, which functions to facilitate breastfeeding (15). 
Theme 5: The desire to consume the postpartum traditional herbal medicine in the next pregnancy and delivery

The study finding showed that $85 \%$ postpartum mothers want to consume the postpartum traditional herbal medicine consistently in the next postpartum period. The reason is because they have experienced many of benefits from consuming it. Meanwhile, $15 \%$ other postpartum mothers were hesitant to consume postpartum traditional herbal medicine in the future postpartum period. They stated that the decision to consume or not were depend on the future postpartum period conditions.

\section{CONCLUSION AND RECOMMENDATION}

Based on the results of the study, it can be concluded that postpartum women who consume postpartum traditional herbal medicine had different perspectives in viewing postpartum herbal medicine. In general, mothers experiencing the benefits directly when consuming postpartum traditional herbal medicine. The benefits were the convenience of the puerperium recovery process and the increase of breast milk production.

\section{REFERENCES}

1. Satriyati E, Peramu A, Pengguna D. Menjaga Tradisi Minum Jamu Madura Dengan Penyampaian Pesan Interpersonal Kesehatan. Dimensi. 2017;

2. Handayani L, Suharmiati S, Sakirno $S$, Djoerban B, Soegijono K, Pranata S. Inventarisasi Jamu Madura Yang Dimanfaatkan Untuk Pengobatan Atau Perawatan Gangguan Kesehatan Berkaitan Dengan Fungsi Reproduksi Wanita. Bul Penelit Sist Kesehat. 2012;

3. Mirong ID. Bahan Ajar Asuhan Kebidanan Nifas dan Menyusui. Kementeri Kesehat RI. 2018;
4. Mansyur, Nurliana. Kasrinda D. Asuhan Kebidanan Masa Nifas. Jurnal Chem Inf Model. 2019;

5. Paryono, Kurniarum A. Kebiasaan Konsumsi Jamu Untuk Menjaga Kesehatan Tubuh Pada Saat Hamil dan Setelah Melahirkan Di Desa Kajora Klaten Selatan. Jurnal Terpadu IImu Kesehat. 2014;

6. Kumalasari R, Arimbi D, Ismunandar A. Pemberian Jamu Uyup - Uyup Terhadap Kelancaran Pengeluaran Air Susu Ibu (Asi) Pada Ibu Nifas. Pros Seminar Nasional Int. 2014;

7. prastiwi ratih sakti. Pengobatan Tradisional (Jamu) dalam Perawatan Kesehatan Ibu Nifas dan Menyusui di Kabupaten Tegal. Siklus Jurnal Res Midwifery Politek Tegal. 2018;

8. Huberman MBM dan AM. Analisis Data Kualitatif, Buku Sumber Tentang MetodeMetode Baru. Penerbit Universitas Indonesia (Ul-Press). 2014.

9. N. Faktor - faktor yang Berhubungan dengan Penggunaan Obat-obatan Tradisional terhadap Ibu Nifas di Puskesmas Karanggan Kabupaten Bogor 2018. Jurnal Kesehatan Indra Husada. 2019;

10. Yunitasari E, Aulia Nastiti A, Jessica Sari DJ. Factors Associated with the Habit of Drinking Jamu in Madurese Postpartum Mothers. In 2017.

11. Imron A. Implementasi Kebijakan Kesehatan "Libas 2+" Sebagai Upaya Menurunkan Angka Kematian Ibu dan Bayi di Kabupaten Sampang. Jurnal Kebijak Kesehat Indones. 2013;

12. Istiqomah Sri Banun, Istiqomah SBT, Fatmawati S, Fitriana WD, Ersam T. Analysis of Consumption Habits of PostPartum Herbal Concoction in Postpartum Mothers. In 2020. 
13. Uji Antifungi Ramuan Tradisonal Madura "Subur Kandungan." Uji Antifung Ramuan Tradisonal Madura "Subur Kandungan." 2016;

14. Studi Etnobotani Pengobatan Tradisional untuk Perawatan Wanita di Masyarakat
Keraton Surakarta Hadiningrat. Biosaintifika Jurnal Biol Biol Educ. 2014;

15.Prabasiwi A, Fikawati S, Syafiq A. ASI Eksklusif dan Persepsi Ketidakcukupan ASI. Kesmas Natl Public Health Jurnal. 2015; 